\title{
Empowerement of Trained Health Volunteers to Increase Detection Rate of Children with Developmental Delay in Urban Kendal, Indonesia
}

\author{
$1^{\text {st }}$ Lukman Fauzi \\ Public Health Science \\ Department \\ Faculty of Sports Science \\ Universitas Negeri Semarang \\ Semarang, Indonesia \\ lukman.ikm@mail.unnes.ac.id
}

\author{
$2^{\text {nd }}$ Sri Ratna Rahayu \\ Public Health Science \\ Department \\ Faculty of Sports Science \\ Universitas Negeri Semarang \\ Semarang, Indonesia \\ sriratnarahayu@mail.unnes.ac.id
}

\author{
$3^{\text {rd }}$ Lindra Anggorowati \\ Public Health Science \\ Department \\ Faculty of Sports Science \\ Universitas Negeri Semarang \\ Semarang, Indonesia \\ lindraanggorowati@gmail.com
}

\author{
$4^{\text {th }}$ Nimas Dwi Ayu Rizki \\ Public Health Science \\ Department \\ Faculty of Sports Science \\ Universitas Negeri Semarang \\ Semarang, Indonesia \\ nimasdayuu@gmail.com
}

\begin{abstract}
Early detection at integrated health post in Kendal is only in growth aspect. Health workers and volunteers never measure and monitor developmental aspect among children. This makes developmental delay among them cannot be early detected and treated. Trained health volunteers (HV) are HV who are trained in children development measurements based on PreScreening Development Questionnaire (KPSP) and regularly monitor children. The aim was to know the effect of trained HV on HV's knowledge and attitude about children development, and incidence rate of children with developmental delay detected. It was quasi experiment with pretest posttest control group design. Monitoring was conducted by HV once a month for 3 months in Pegulon and Patukangan Villages as experimental groups and Bandengan and Ketapang Villages as control groups. Collected data were analyzed with t-test. Knowledge posttest score among trained and untrained HV respectively was 74.2+5.07 and 67.9+4.37, while attitude was $80.9+4.53$ and 71.0+4.48. There was difference of knowledge and attitude on children development between trained and untrained HV $(p<0.001)$. Incidence rate of children with developmental delay detected by trained HV was 18 suspects per 1000 childrenmonths. Trained HV was proven to increase detection rate of children with developmental delay in urban area.
\end{abstract}

Keywords - trained HV, developmental delay, detection

\section{INTRODUCTION}

Children have a characteristic that always grows and develops from the time of conception until the end of adolescence [1]. Growth is different from development. Growth is an increase in the size and number of cells and intracellular tissues, so that it can be interpreted as increasing the physical size and structure of the body partly or completely [2]. Growth is quantitative so it can be measured using units of length and weight. The development is the addition of the ability of the structure and function of the body more complex, so that the measurement is much more difficult than growth [3, 4].

Children's growth and development from the mother's womb until age 6 years will determine the degree of health, intelligence, emotional and spiritual maturity, and productivity at the next level [5]. The development of speech and language, intelligence, social awareness, moral, and emotional work quickly in infancy and become the foundation for further development. Even the slightest deviation if not detected, not handled properly will reduce the quality of human resources in the future [4]. The Government of Indonesia has efforts to overcome the problem of growth and development in the form of stimulation, detection, and intervention programs of growth and development, but its implementation is not optimal and still not well monitored.

The implementation of the program in primary health care in Semarang was still limited because it has not been socialized properly and correctly, inadequate supporting facilities, and lack of support from primary health care. This made the final goal of the program has not been achieved as expected. Programs implemented was only early detection of growth delay, whereas early detection of developmental delay, emotional mental disorders, and age-appropriate stimulation have not been implemented [6].

Early detection of child's growth and development is an activity to determine early growth and developmental delay/deviation among infants and preschoolers. Aspects seen from this early detection is the aspect of growth and development. The growth aspect relates to body weight, height, and head circumference of child. The developmental aspects associated with gross and fine motor skills, language, and social [7]. With early detection of child developmental problems, interventions are easier to perform, health workers also have time in appropriate interventions. If the deviation is

This study was primarily granted funding from Directorate of Research and Community Services, Ministry of Research, Technology, and Higher Education of the Republic of Indonesia. 
late known, then the intervention will be more difficult and affect the child's growth and development [4].

Early detection at integrated health post in Kendal is only in growth aspect. Health workers and volunteers never measure and monitor developmental aspect among children. This makes developmental delay among them cannot be early detected and treated. Children in Urban Kendal who did not receive exclusive breastfeeding and early initiation of breastfeeding and experienced developmental was $60.8 \%$, while $8.7 \%$ of children who received both experienced developmental delay [8].

One of the main activities at integrated health post is to measure growth and development regularly. The types of services provided by integrated health post for children under five are: 1) weight weighing, 2) determination of growth status, 3 ) health promotion and counseling, 4) medical examination, immunization and early detection of growth and development. If found abnormalities, immediately referred to primary health care [4].

Integrated health post activities in Kendal that have been running regularly every month should be the right opportunity to be utilized in optimizing the measurement of children development. Measurement of development is an activity that should be done routinely every 3 months from 3 months to 72 months to monitor and detect early chances of developmental delay. There is no activity in Table 2 of integrated health post that is supposed to be a place of growth and development measurement for mother and children. During this time, the integrated health post activities are still very simple, by just measuring the baby's weight and recording the results on the card and register book. The absence of measurement of children development is due to the health volunteers not having enough knowledge and ability to do. In addition, unavailability of instruments and equipment required in measuring children development is also a cause.

Trained health volunteers (HV) are HV who are trained in children development measurements based on Pre-Screening Development Questionnaire and regularly monitor children. The aim of this study was to know the effect of trained HV on HV's knowledge and attitude about children development, and incidence rate of children with developmental delay detected.

\section{MATERIALS AND METHODS}

This study was quasi experiment with pretest posttest control group design. Experiment group consisted of $30 \mathrm{HV}$ in Pegulon and Patukangan who were trained in child development measurements based on a Pre-Screening Development Questionnaire and regularly monitored child development. The control group were $30 \mathrm{HV}$ in Ketapang and Bandengan who were not trained.

Both groups were measured knowledge and attitude before and after intervention. After training, trained $\mathrm{HV}$ monitor children development for 3 months. Incidence rate of children with developmental delay detected by $\mathrm{HV}$ was calculated. Knowledge and attitude data were analyzed by t-test.

\section{RESULTS AND DISCUSSION}

Characteristics of trained and untrained $\mathrm{HV}$ on the educational and employment aspects were not much different. Most educational levels for trained and untrained HV were junior high school (55.6\% and 44.4\%). At employment, most of the employement of trained and untrained $\mathrm{HV}$ were entrepreneurs (44.1\% and $55.9 \%)$. Characteristics of education and employment of $\mathrm{HV}$ can be seen in the following table.

TABLE I. HV CHARACTERISTICS BASED ON EDUCATION AND EMPLOYMENT

\begin{tabular}{|l|r|r|r|r|r|r|}
\hline \multirow{2}{*}{ Variable } & \multicolumn{2}{|c|}{ Trained } & \multicolumn{2}{c|}{ Untrained } & \multicolumn{2}{c|}{ Total } \\
\cline { 2 - 7 } & \multicolumn{1}{|c|}{$n$} & $\%$ & \multicolumn{1}{c|}{$n$} & $\%$ & $n$ & $\%$ \\
\hline Education & & & & & & \\
- Elementary school & 4 & 44.4 & 5 & 55.6 & 9 & 100 \\
- Junior high school & 15 & 55.6 & 12 & 44.4 & 27 & 100 \\
- Senior high school & 9 & 47.4 & 10 & 52.6 & 19 & 100 \\
- College & 2 & 40.0 & 3 & 60.0 & 5 & 100 \\
\hline Employment & & & & & & \\
- Housewife & 13 & 59.1 & 9 & 40.9 & 22 & 100 \\
- Entrepreneneur & 15 & 44.1 & 19 & 55.9 & 34 & 100 \\
- Civil servant & 2 & 50.0 & 2 & 50.0 & 4 & 100 \\
\hline
\end{tabular}

Knowledge and attitude score of trained HV before and after training showed a difference $(\mathrm{p}<0.001)$. Knowledge pretest score was $69.0 \pm 3.98$ increased to $74.2 \pm 5.07$ after training. As well as in the attitude aspect, it increased from $72.1 \pm 3.72$ to $80.9 \pm 45.3$. Unlike untrained $\mathrm{HV}$, knowledge and attitude score did not differ significantly. Knowledge pretest and posttest scores were $67.9 \pm 4.38$ and $67.9 \pm 4.37$, so there was no significantly difference (p: 0.54). As in the attitude aspect, although there was an increase from $70.9 \pm 4.18$ to $71.0 \pm 4.48$, it did not differ significantly (p: 0.42). Table 2 shows different test results on the knowledge and attitude aspects among trained and untrained $\mathrm{HV}$.

TABLE II. KNOWLEDGE AND ATTITUDE SCORE AMONG TRAINED AND UNTRAINED HV

\begin{tabular}{|c|l|l|c|c|}
\hline Group & Variable & \multicolumn{1}{|c|}{ Test } & Mean \pm SD & p-value \\
\hline Trained & \multirow{2}{*}{ Knowledge } & Pre & $69.0 \pm 3.98$ & $<0.001$ \\
\cline { 3 - 4 } & & Post & $74.2 \pm 5.07$ & \\
\cline { 3 - 4 } & Attitude & Pre & $72.1 \pm 3.72$ & $<0.001$ \\
\cline { 3 - 4 } & & Post & $80.9 \pm 4.53$ & \\
\hline Untrained & \multirow{2}{*}{ Knowledge } & Pre & $67.9 \pm 4.38$ & 0.54 \\
\cline { 3 - 4 } & & Post & $67.9 \pm 4.37$ & \\
\cline { 2 - 4 } & Attitude & Pre & $70.9 \pm 4.18$ & 0.42 \\
\cline { 3 - 4 } & & Post & $71.0 \pm 4.48$ & \\
\hline
\end{tabular}

TABLE III. KNOWLEDGE AND ATTITUDE (POSTTEST-PRETEST) SCORE BETWEEN TRAINED AND UNTRAINED HV

\begin{tabular}{|c|c|c|c|}
\hline Variable & Group & Mean \pm SD & p-value \\
\hline $\begin{array}{c}\text { Knowledge } \\
\text { (post-pre) }\end{array}$ & Trained & $5.6 \pm 4.47$ & $<0.001$ \\
\cline { 2 - 3 } & Untrained & $0.27 \pm 0.52$ & \\
\hline $\begin{array}{c}\text { Attitude } \\
\text { (post-pre) }\end{array}$ & Trained & $8.83 \pm 3.36$ & $<0.001$ \\
\cline { 2 - 3 } & Untrained & $0.37 \pm 0.56$ & \\
\hline
\end{tabular}

Table 3 shows the differences of knowledge and attitudes between trained and untrained HV. Difference between pretest and posttest of each group is used as comparison. The results 
showed that there was a difference of knowledge and attitude on children development between trained and untrained HV ( $p$ $<0.001)$.

Of the 30 trained $\mathrm{HV}$, there were $23 \mathrm{HV}$ (76.7\%) periodically monitored children development aged 3 months 5 years 11 months for 3 months in their area. In contrast, all untrained HV did not monitor children development.

Children measured by trained HV were 57 children and 3 children of whom were children with developmental delay. It can be concluded that the incidence proportion of children with developmental delay in urban Kendal was 5\%, while incidence rate of children with developmental delay detected by trained HV was 18 suspects per 1000 children-months.

Growth and development are influenced by several factors, one of which is health care. Regular health care is not only when the child is sick, but health screening and early detection of growth and development are necessary to be done routinely, so that support children growth and development [9]. One of the efforts to develop children under five development which has been implemented by the Ministry of Health of Indonesia is early detection and stimulation of children growth and development in basic service level. This effort aims to find out early on the existence of growth and development deviances among children. This effort is carried out in integrated health post as a routine activity to help children achieve optimal growth and development, then they become qualified, healthy, intelligent, creative, and productive human beings [10].

Children who receive responsive stimulation will have higher cognitive, linguistic and motoric abilities than those who are not stimulated [11]. In other countries such as Cuba there are repeat visits to the home by physicians in the year after the baby is born which promotes optimal nutrition and early childhood development [12].

$\mathrm{HV}$ are the groups that most often interact with the community, then they have a very strategic position and an effective means of communicating messages related to health problems either in integrated health post or in the surrounding environment. Therefore, they need good knowledge to motivate people to prevent and detect developmental delays. The role of HV is to take responsibility, develop capabilities, become actors and pioneers as well as leaders who mobilize communities based on the principle of independence and togetherness [13]. In some countries, such as Ethiopia, Niger and Mali, HV (known as the Health Development Army in Ethiophia and Relais Communautaire in Mali and Niger) play an important role in promoting keys of healthy family including breastfeeding, infant care, hygiene and sanitation [14].

The role of HV in integrated health post in every village is very important in monitoring the growth and development of early childhood. HV in integrated health post can observe children development every month so as to provide appropriate stimulation for children who come. In some countries, basic services provided include early childhood development. In Pakistan, there are "Lady Health Workers" who do home visit services covering mother counseling practices in childresponsive stimulation [15]. Lack of functioning of integrated health post is due to the ability of HV is still low, including knowledge and skill [16].

Limited knowledge of $\mathrm{HV}$ to understand their duties to assess children development can be attributed to very limited coaching and mentoring mainly from primary health care workers or from health offices. Training is one of the methods to increase the knowledge. Someone who has received training, then his knowledge and skills will improve. Providing information submitted through the training process may replace previously acquired knowledge and as a refinement of prior information [16].

Attitudes were influenced by the evaluative processes undertaken by individuals, influenced by genetic factors, personal experiences, parental influences, peer groups that influence individuals and the mass media. In the process of education or training, an attitude was not necessarily manifest in practice or action. It was still needed certain conditions that allow the change of attitude into practice. These conditions included the availability of facilities for learning in which participants are given the opportunity to see and hear other people performed these skills and given the opportunity to do their own. HV who initially do not understand, after getting child development training, can slowly learn and implement stimulation for children [8].

$\mathrm{HV}$ as the motor of public health should be a reliable communicator in spreading information to the public. The level of $\mathrm{HV}$ practice is supported by higher-capacity $\mathrm{HV}$ who have received education, longer training experience, have salary, and have backgrounds in health improvement efforts [17].

On early detection of development, HV need support or role of existing health workers to provide guidance if they meet difficulty. A health worker is a person who possesses knowledge and skills through health education. In the integrated health post activities, health worker is tasked with carrying out medical assessment and following up on HV's findings. Support from health workers is to provide guidance to HV during or after integrated health post activities in the form of recording and how to improve the ability of $\mathrm{HV}$ in early detection of child's growth and development [10].

\section{CONCLUSION}

There was difference of knowledge and attitude on children development between trained and untrained HV. Incidence rate of children with developmental delay detected by trained HV was 18 suspects per 1000 children-months. Trained HV was proven to increase detection rate of children with developmental delay in urban area

\section{ACKNOWLEDGMENT}

We would like to thank Directorate of Research and Community Services, Ministry of Research, Technology, and Higher Education of the Republic of Indonesia for the funding and all health workers and volunteers involved in the study for their cooperation. 


\section{REFERENCES}

[1] W.C. Chiu, H.F. Liao, P.J. Chang, and Y.C. Chen, "Duration of breastfeeding and risk of developmental delay in Taiwan children: a nationwide birth cohort study," Paediatr Perinat Epidemiol, vol. 6, pp. 519-27, 2011

[2] P. Betrán, M. De Onís, J. Lauer, and J. Villar, "Ecological study of effect of breastfeeding on infant mortality in Latin America." BMJ (Clinical Research Ed.), vol. 323, no. 7308, pp. 303-306, 2001.

[3] N. Angelsen, T. Vik, G. Jacobsen, and L. Bakketeig, "Breastfeeding and cognitive development at age 1 and 5 years, “ Arch Dis Child, vol. 85, no. 3, pp. 183-188, 2001.

[4] MoH of the Republic of Indonesia, "Guidelines for the implementation of early childhood growth stimulation detection and intervention at basic health service level," Jakarta, 2010.

[5] A. Sagala, and I. Khasanah, "Early childhood development of integrative holistic design in non-formal early childhood," Indonesian Journal of Early Child-hood Education Studies, vol. 4, no. 1, pp. 1-10, 2015.

[6] D. Maritalia, "Early detection and intervention of development and growth among children under five and pre school children at primary health care in Semarang City," unpublished.

[7] O.H. Jonsdottir, I. Thorsdottir, G. Gunnlaugsson, S. Mary, Fewtrell, P.L. Hibberd, and R.E. Kleinman, "Exclusive breastfeeding and developmental and behavioral status in early childhood," Nutrients, vol. 5, pp. 4414-4428, 2013.

[8] L. Anggorowati, "Early initiation of breastfeeding and exclusive breastfeeding as determinants of developmental disorder among 12-24 months old children: Case control study in kendal district," unpublished.

[9] A. Abubakar, F. Van de Vijver, A. Van Baar, L. Mbonani, R. Kalu, C. Newton, and P. Holding, "Socioeconomic status, anthropometric status, and psychomotor development of Kenyan children from resourcelimited settings: a path-analytic study," Early Hum Dev, vol. 84, no. 9, pp. 613-621, 2008.

[10] $\mathrm{MoH}$ of the Republic of Indonesia, "General guidelines for integrated health post management," Jakarta, 2006

[11] A.K. Yousafzai, J. Obradovic, M.A. Rasheed, A. Rizvi, X.A. Potilla, N.T. Strayer, S. Siyal, and U. Memon, "Effects of responsive stimulation and nutrition interventions on children's development and growth at age 4 years in a disadvantaged population in Pakistan: a longitudinal follow-up of a cluster-randomised factorial eff ectiveness trial," The Lancet Glob Health, vol. 4, pp. 548-58, 2016.

[12] E.J. Lawn, Z.A. Bhutta, S. Nwall, S. Peterson, and E. Doviaud, "Cadres, content and costs for community-based care for mothers and newborns from seven countries: implications for universal health coverage," Health Policy and Planning, vol. 32, Suppl. 1, 2017.

[13] F. Abdullah, "Knowledge and motivation of cadres in implementing early detection of child growth at integrated health post at Kalumpang Primary Health Care," IEEE Transl. Jurnal Riset Kesehatan, vol. 6, no. 2, pp. 48-54, 2017.

[14] N. Leon, D. Sanders, and W. Van Damme, "The role of 'hidden' community volunteers in community-based health service delivery platforms: examples from sub-Saharan Africa," Global Health Action, vol. 8, no. 27214, 2015.

[15] A.K. Yousafzai, M.A. Rasheed, A. Rizvi, R. Armstrong, and Z.A. Bhutta, "Effect of integrated responsive stimulation and nutrition interventions in the Lady Health Worker programme in Pakistan on child development, growth, and health outcomes: a cluster-randomised factorial effectiveness trial," The Lancet, vol. 384, no. 9950, pp. 128293, 2014.

[16] H.M. Fitri, and Mardiana, "Training for skills of integrated health post cadre," IEEE Transl. KEMAS, vol. 7, no. 1, pp. 22-27, 2011. 